\title{
Sprawozdanie z XII Sympozjum Naukowo-Szkoleniowego Polskiego Towarzystwa Dermatologicznego - Polska Akademia Dermatologii i Wenerologii
}

\author{
Kielce, 18-20 kwietnia 2018 roku
}

Dermatol Rev/Przegl Dermatol 2018, I05, 324-327

W dniach 18-20 kwietnia 2018 roku w Kielcach, w Hotelu Binkowski odbyła się XII edycja Polskiej Akademii Dermatologii i Wenerologii. Tegoroczne sympozjum miał zaszczyt współorganizować Oddział Świętokrzyski Polskiego Towarzystwa Dermatologicznego (PTD). Patronat honorowy nad wydarzeniem objęli prezydent Kielc oraz rektor Uniwersytetu Jana Kochanowskiego w Kielcach. W konferencji wzięło udział blisko 400 uczestników, którzy mieli możliwość wysłuchania 47 wykładów przedstawionych przez wybitnych specjalistów z zakresu dermatologii i wenerologii w 9 sesjach tematycznych.

Konferencję poprzedziło posiedzenie Zarządu Głównego PTD oraz 2,5-godzinne warsztaty „Lecze-

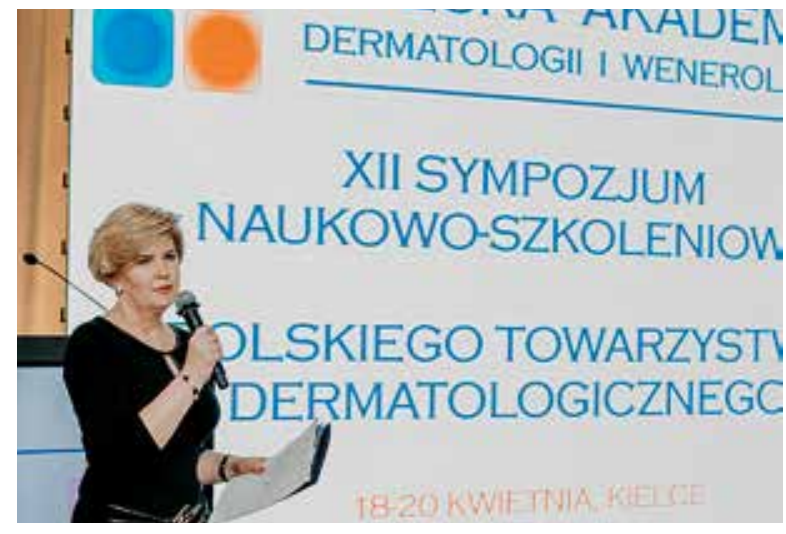

Rycina I. Profesor Beata Kręcisz, organizatorka sympozjum PTD

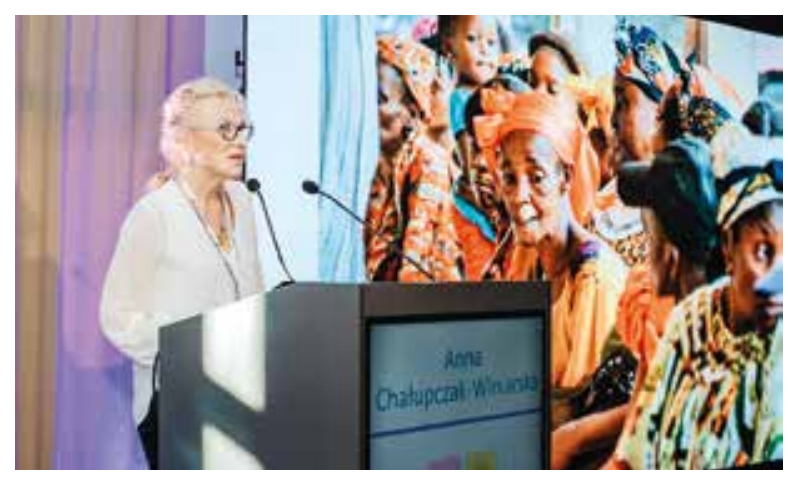

Rycina 3. Wykład dr Anny Chałupczak-Winiarskiej nie pacjenta $\mathrm{z}$ łuszczycą - szczególne sytuacje $\mathrm{w}$ trakcie leczenia biologicznego na podstawie przypadków klinicznych" zorganizowane we współpracy z firmą Eli Lilly Polska, w których wzięło udział 50 lekarzy. Ponadto zgodnie z wieloletnią tradycją sympozjum dla lekarzy specjalizujących się w zakresie dermatologii i wenerologii zorganizowano trzydniowy kurs: „Diagnostyka kliniczna i laboratoryjna oraz leczenie alergicznych chorób skóry".

Uroczystego otwarcia konferencji dokonały prezes Polskiego Towarzystwa Dermatologicznego prof. Lidia Rudnicka i przewodnicząca Oddziału Świętokrzyskiego PTD prof. Beata Kręcisz. Spotkanie uświetnili obecnością przedstawiciele władz

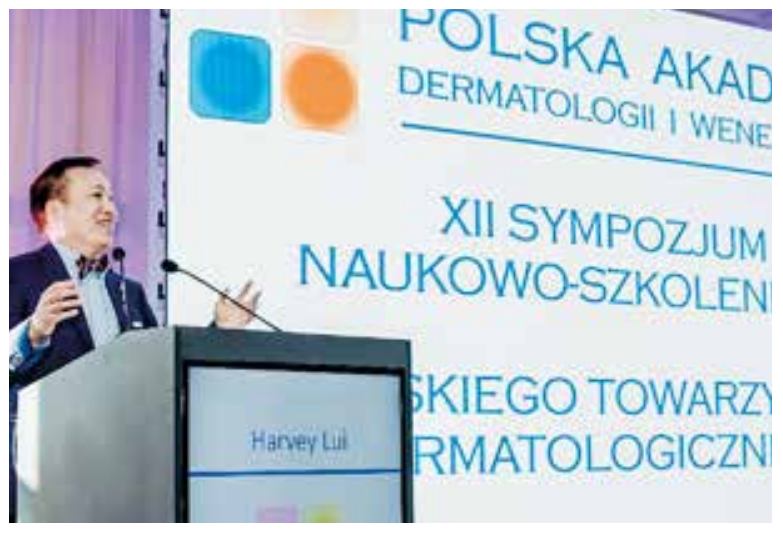

Rycina 2. Profesor Harvey Lui

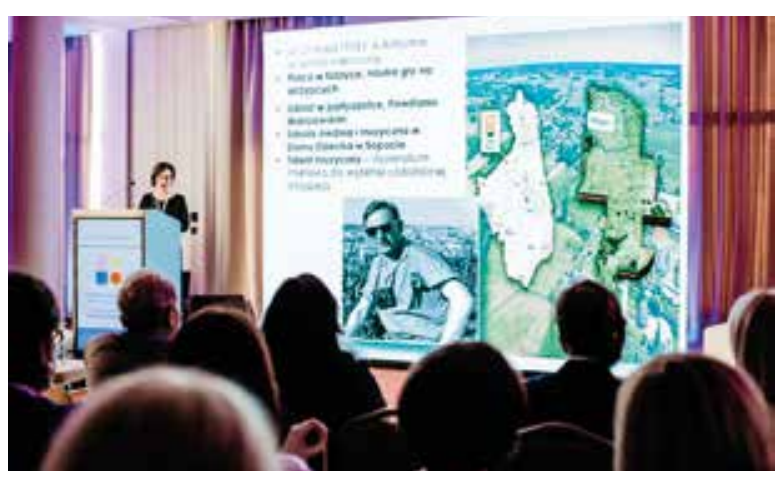

Rycina 4. Profesor Dorota Krasowska podczas wykładu im. prof. Tadeusza Chorzelskiego 


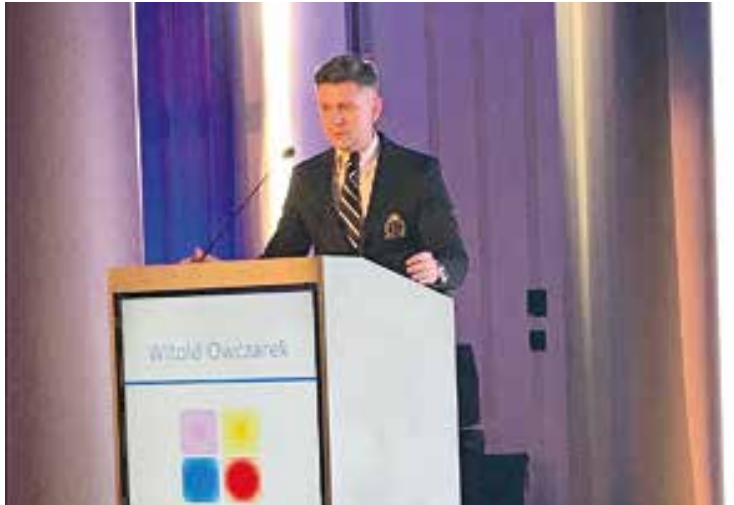

Rycina 5. Profesor Witold Owczarek podczas wykładu im. prof. Mariana Grzybowskiego

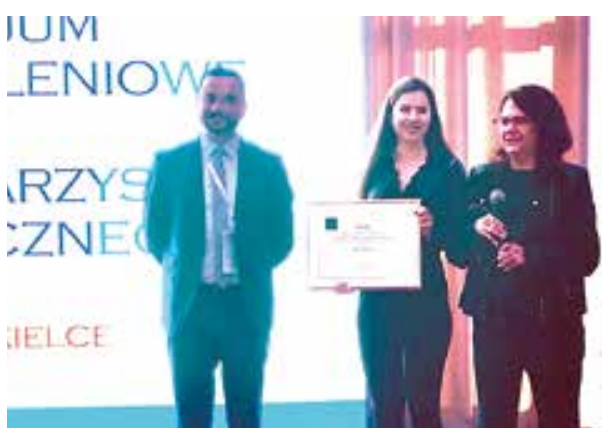

Rycina 7. Nagroda PTD - grant naukowy dla dr Edyty Lelonek

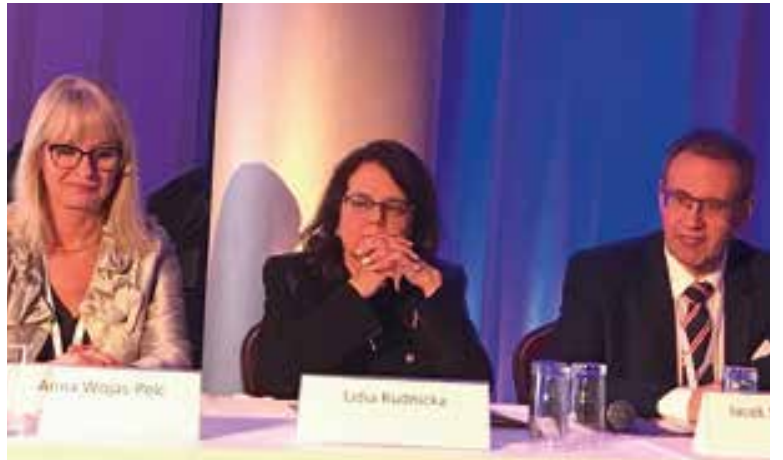

Rycina 9. Przewodniczący sesji: prof. Anna Wojas-Pelc, prof. Lidia Rudnicka, prof. Jacek Szepietowsk

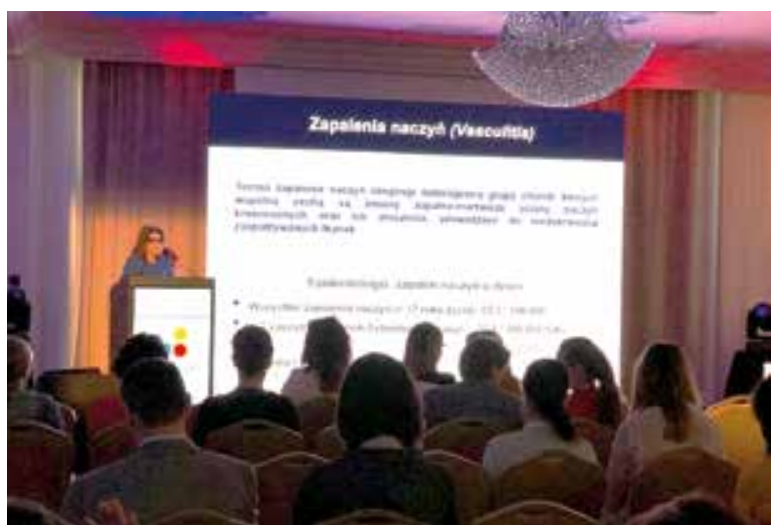

Rycina II. Profesor Magdalena Lange

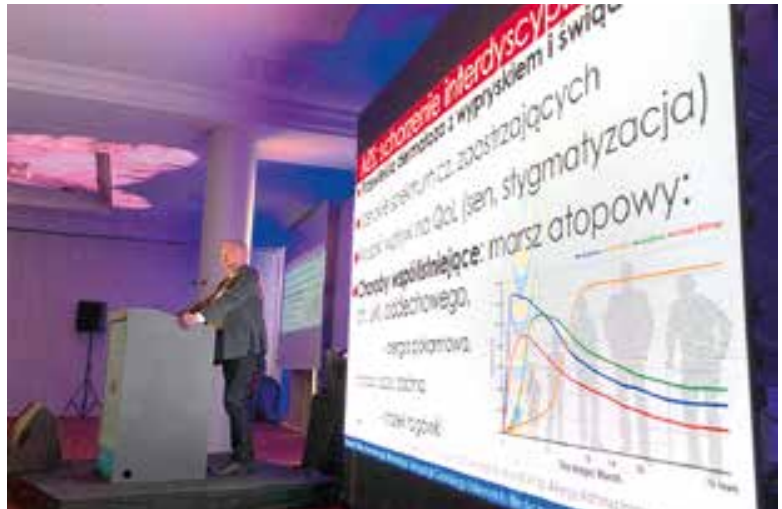

Rycina 6. Profesor Roman J. Nowicki podczas wykładu im. prof. Edwarda Rudzkiego

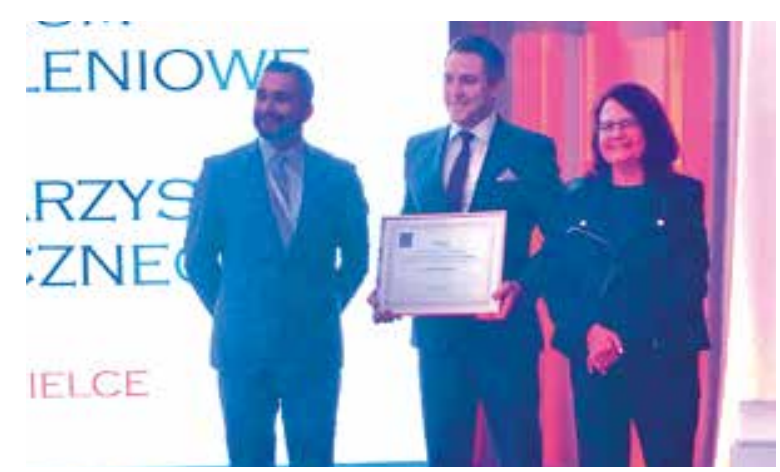

Rycina 8. Nagroda PTD - grant naukowy dla dr. hab. Łukasza Matusiaka

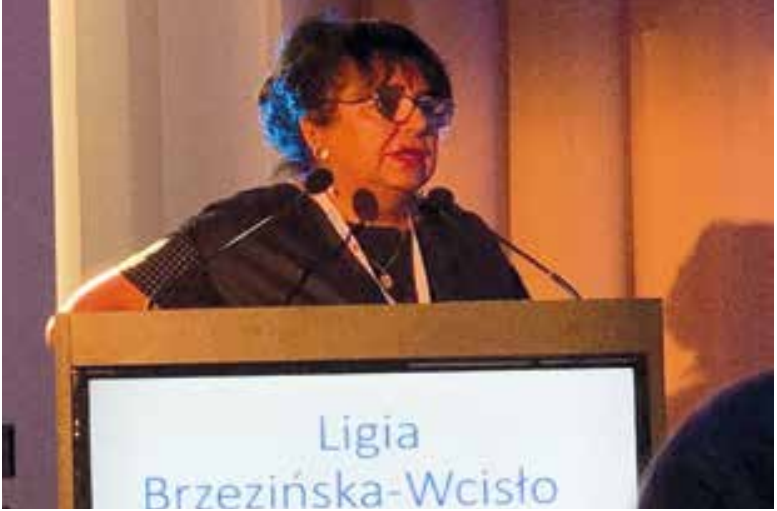

Rycina I0. Profesor Ligia Brzezińska-Wcisło

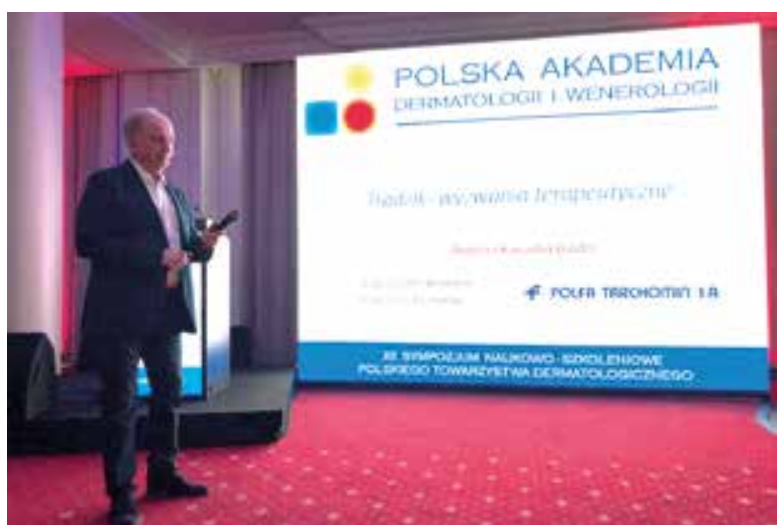

Rycina I2. Profesor Andrzej Kaszuba 


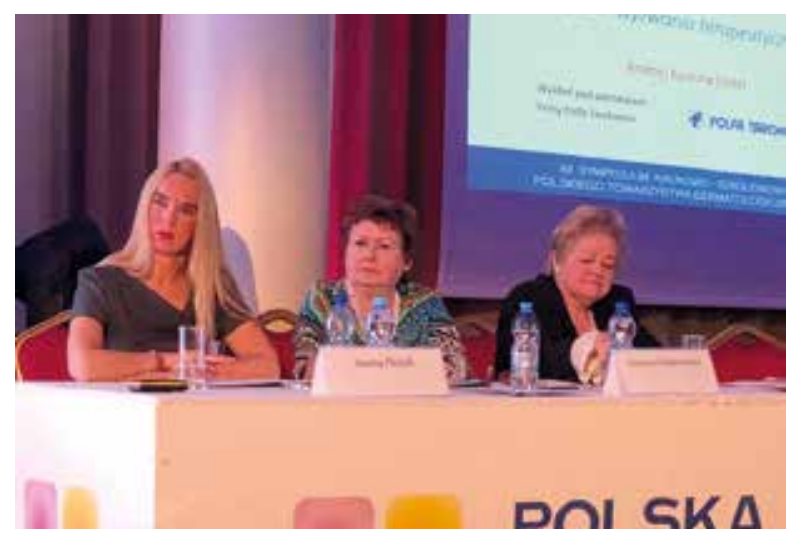

Rycina 13. Przewodniczące sesji: prof. Iwona Flisiak, prof. Grażyna Chodorowska i dr Monika Kapińska-Mrowiecka

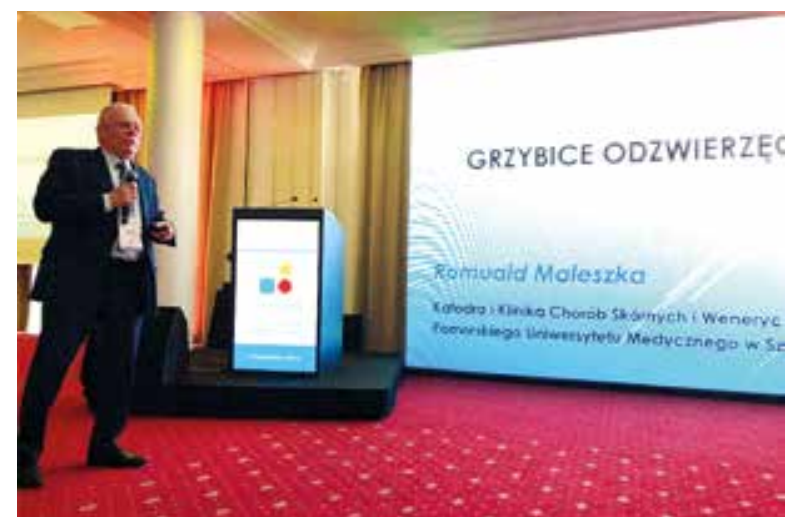

Rycina 15. Profesor Romuald Maleszka

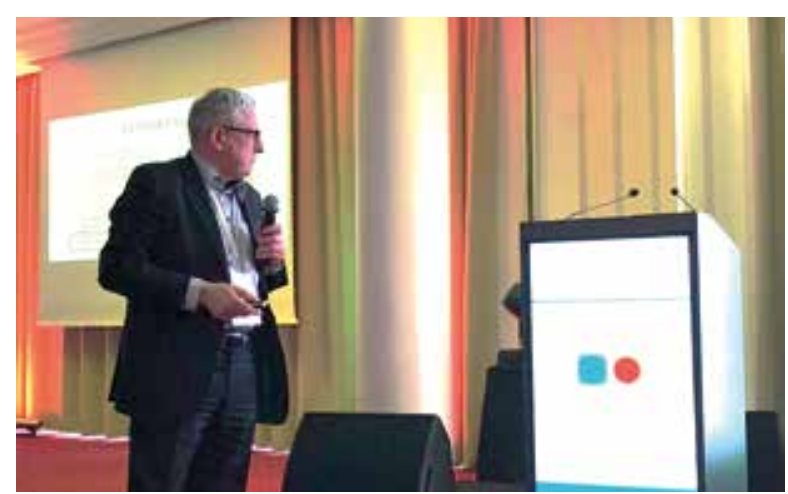

Rycina 17. Profesor Zygmunt Adamski

miasta Kielc, Uniwersytetu Jana Kochanowskiego oraz dyrekcji Wojewódzkiego Szpitala Zespolonego w Kielcach. Gościem specjalnym konferencji był prof. Harvey Lui, wybitny specjalista z zakresu dermatologii i fotobiologii, prezydent Międzynarodowej Ligi Towarzystw Dermatologicznych, który podczas ceremonii otwarcia wręczył nagrody przyznane przez ILDS dr Annie Chałupczak-Winiarskiej, ambasadorce Fundacji Dzieci Afryki za udział w misjach medycznych niosących pomoc lekarską potrzebującym w krajach Afryki Środkowej oraz prof. Jackowi

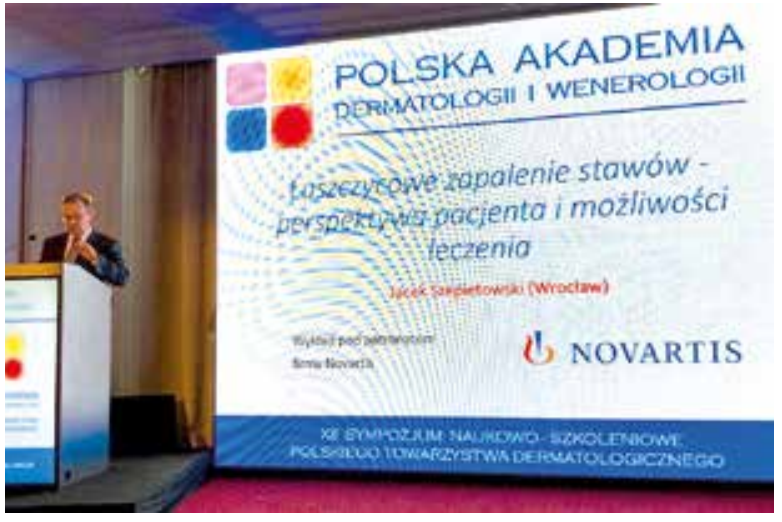

Rycina I4. Profesor Jacek Szepietowski

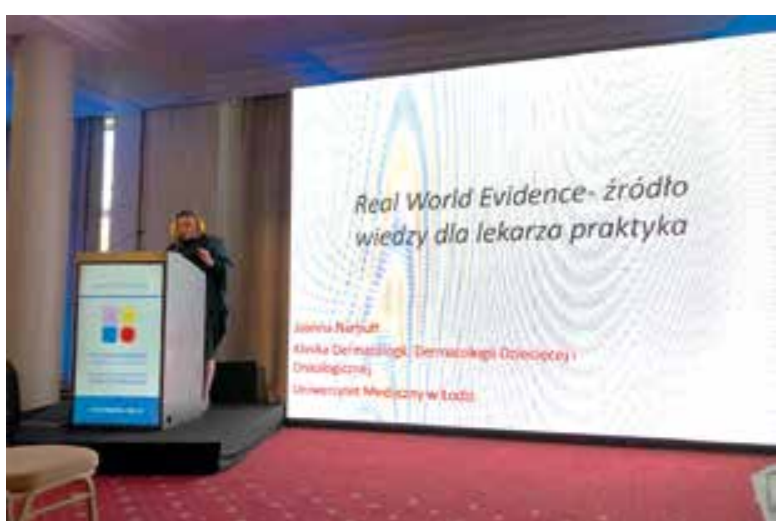

Rycina 16. Profesor Joanna Narbutt

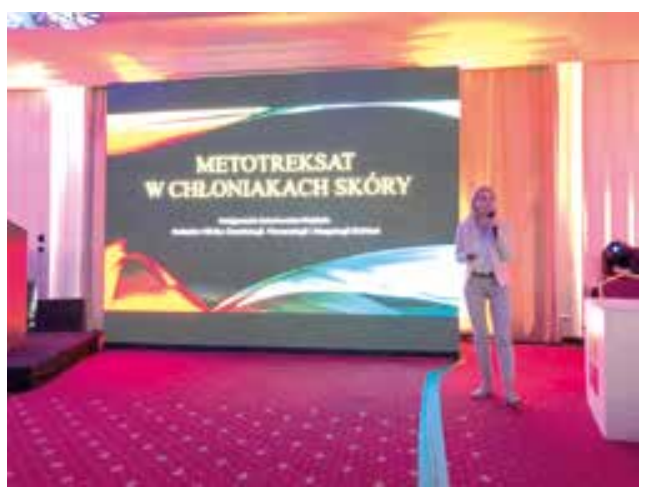

Rycina I8. Profesor Małgorzata Sokołowska-Wojdyło

Szepietowskiemu za osiągnięcia naukowe i aktywny wkład w rozwój dermatologii i wenerologii na forum międzynarodowym. $W$ trakcie otwarcia konferencji ogłoszono również wyniki konkursu Zarządu Polskiego Towarzystwa Naukowego na najlepszą publikację naukową opublikowaną przez członka PTD w 2017 roku. Nagrody w postaci grantów naukowych na wyjazd na konferencję EADV w Paryżu otrzymali: lek. Edyta Lelonek za artykuł: Aquagenic pruritus in polycythemia vera: a cross-sectional study oraz dr hab. med. Łukasz Matusiak za artykuł: Increased interleukin 
(IL)-17 serum levels in patients with hidradenitis suppurativa: implications for treatment with anti-IL-17 agents. Oba artykuły zostały opublikowane w Journal of the American Academy of Dermatology. Tegoroczni laureaci pochodzą z Kliniki Dermatologii, Wenerologii i Alergologii Uniwersytetu Medycznego we Wrocławiu. Wszystkim nagrodzonym serdecznie gratulujemy.

W sesji inauguracyjnej przedstawiono wykłady poświęcone pamięci wybitnych polskich dermatologów. Wykłady im. prof. Mariana Grzybowskiego, prof. Tadeusza Chorzelskiego oraz prof. Edwarda Rudzkiego wygłosili: prof. Witold Owczarek (Wspótczesne i przyszłe możliwości leczenia raka skóry), prof. Dorota Krasowska (Twardzina układowa - rekomendacje diagnostyczno-terapeutyczne PTD w praktyce) oraz prof. Roman J. Nowicki (Atopowe zapalenie skóry - możliwości terapeutyczne dziś i jutro). Drugiego dnia konferencji odbyła się uroczysta sesja im. prof. Wiesława Glińskiego, pomysłodawcy i wieloletniego organizatora Polskiej Akademii Dermatologii i Wenerologii, którą uświetnił wykład prof. Harveya Lui: New insights in photoprotection - how much do you really know? W kolejnych sesjach tematycznych prezentowano najnowsze doniesienia w zakresie diagnostyki, różnicowania i terapii dermatoz. Wszystkie sesje cieszyły się dużym zainteresowaniem, co przełożyło się na wysoką frekwencję na sali wykładowej. W przerwach pomiędzy sesjami można było odwiedzić stoiska wydawnictw medycznych oraz firm farmaceutycznych.

Na zakończenie sympozjum wyróżniono 6 najlepszych prezentacji przypadków klinicznych przedstawianych w trakcie spotkania. Wśród wyróżnionych znaleźli się: lek. Justyna Czarny, lek. Agata Kłosowicz, lek. Monika Kucharczyk, lek. Piotr Parcheta, dr n. med. Mariusz Sikora, lek. Sylwia Cyran-Stemplewska.

W rozmowach kuluarowych uczestnicy podkreślali wysoki poziom naukowy wykładów, jak również walory miejsca, w którym odbywała się konferencja, co niewątpliwie przyczyniło się do dobrej atmosfery podczas sympozjum.

W imieniu Komitetu Naukowego i Organizacyjnego pragnę serdecznie podziękować przewodniczącym sesji naukowych, wykładowcom, uczestnikom, sponsorom oraz firmie organizacyjnej Symposium Cracoviense za aktywny wkład, obecność i zaangażowanie w realizację tego wspólnego przedsięwzięcia.

prof. Beata Kręcisz 